TARNOWSKIE STUDIA TEOLOGICZNE 34 (2015) NR 2, S. 115-128

http://dx.doi.org/10.15633/tst.1642

Tatiana Krawczyńska-Zaucha ${ }^{1}$

UNIWERSYTET PAPIESKI JANA PAWŁA II W KRAKOWIE

\title{
W poszukiwaniu spełnienia
}

Każdemu odmierzone jest to, czym jest, oraz jego bycie. Można je jednak nazwać doskonałym o tyle, o ile osiągnęło właściwą sobie pełnię: jest całkowicie tym, czym ma być, i stoi na najwyższym osiągalnym dla niego stopniu bytowania. Jeżeli jestestwo jest stworzeniem rozwijającym się, to najwyższa miara jego bytowania jest celem całego jego dążenia ${ }^{2}$.

Edyta Stein

Od zarania dziejów człowiek poszukuje sensu i celu życia. Cała historia filozofii jest wielkim poszukiwaniem. Poszukiwaniem uzasadnienia istnienia, poszukiwaniem sensu istnienia, poszukiwaniem najgłębszej istoty człowieczeństwa. Dzisiejsze czasy dopisują kolejne rozdziały poszukiwań człowieka. Dziś, w świecie naznaczonym konsumpcją, upadkiem tradycyjnych wartości i autorytetów oraz pogłębiającym się zagubieniem jednostki w społeczeństwie, człowiek nadal poszukuje siebie samego, wracając do zadawanych już w starożytności pytań o sens i cel swojego istnienia. Ma jednak dużą przewagę w stosunku do swoich poprzedników. Może sięgnąć do nieograniczonej literatury filozoficznej, teologicznej, mistycznej czy psychologicznej, aby odpowiedź, którą znajdzie, rzeczywiście harmonizowała z jego człowieczeństwem.

W niniejszym rozważaniu wejdziemy w nurt tych poszukiwań od nieoczywistej strony - od strony spełnienia. Spełnienia rozumianego, podobnie jak w powyższym cytacie Edyty Stein, jako osiągniecie przez człowieka

1 Tatiana Krawczyńska-Zaucha, filozof, teolog, biofizyk, doktorantka UPJPII. Przez 12 lat pracowała w międzynarodowych korporacjach na różnych poziomach strategicznego zarządzania. Obecnie trener i coach w firmie sEDMo. Szkoli i prowadzi coaching dla menedżerów, kierowników, pracowników administracji publicznej, osób duchownych, nauczycieli oraz rodziców.

2 E. Stein, Byt skończony a byt wieczny, tłum. I. Adamska ocd, Poznań 1995, s. 330. 
„właściwej dla niego pełni”, kiedy staje się on „tym, czym ma być”’. Aby zrozumieć spełnienie, wprowadzimy pojęcie pragnienia, interpretowanego dynamicznie ${ }^{4}$ i poszukamy jego konotacji ze spełnieniem. Spełnienie jest bowiem następstwem wypełnienia się pragnienia, które jest i zarazem staje się w człowieku. Trzon rozważań będą stanowiły klasyczne opisy szczęścia u Sokratesa, Arystotelesa i św. Tomasza. Porównamy zawartość pojęcia spełnienia ze słowem „szczęście”, próbując odpowiedzieć na pytanie, czy są one tożsame, czy może jedno wynika $\mathrm{z}$ drugiego lub zawiera się $\mathrm{w}$ tym drugim. Następnie zastanowimy się, czy i ewentualnie jaką rolę odgrywa znalezienie i wyznaczenie przez jednostkę celu lub celów w życiu, które są pomocne w osiągnięciu spełnienia. Na koniec odniesiemy się do współczesnego człowieka, żyjącego w społeczeństwie xxI wieku, by odpowiedzieć na pytanie, czy w ogóle i jeśli tak, to w jakiej mierze, dzisiejszy człowiek może żyć spełnionym życiem.

Niniejsze rozważania są tylko wstępem do poszukiwań spełnienia w życiu człowieka i nie roszczą sobie prawa do podania jakichkolwiek jednoznacznych odpowiedzi. Z jednej bowiem strony poszukiwanie spełnienia musi odbywać się na polu różnych nauk, począwszy od psychologii, poprzez filozofię, teologię, socjologię, na szeroko pojętym rozwoju osobistym skończywszy. Takie działania zawsze niosą ze sobą jakieś niebezpieczeństwa, np. różne definicje tego samego pojęcia, odmienne założenia, rozbieżne wnioski. Dlatego poszukiwanie spełnienia najlepiej byłoby umieścić na płaszczyźnie zintegrowanego człowieczeństwa, które samo byłoby przedmiotem zainteresowania wielu nauk. $Z$ drugiej zaś strony, nie ma i nie może być jednego rozumienia spełnienia. Oczywiście, można wyjść od ogólnej teorii, czym jest spełnienie. Ale szczegółową odpowiedź na pytanie: czym dla mnie konkretnie jest spełnienie?, każdy musi odnaleźć sam.

\section{Pragnienie spełnienia}

Określenie sposobu rozumienia spełnienia może nastręczać sporo trudności. Nie chodzi jednak o to, aby analizować zawartość tego słowa pod różnymi

\footnotetext{
Tamże.

4 Inspirację dotyczącą „pragnienia” w tym artykule, szczególnie w kontekście dynamicznym, zaczerpnęłam z pracy habilitacyjnej o. M. Zawady ocD, Homo desiderans Deum. Dynamika pragnienia Boga w wymiarze antropologiczno-duchowym, Kraków 2011.
} 
kątami i wydobywać różne jego aspekty. W niniejszych rozważaniach będziemy się opierać na rozumieniu spełnienia w taki sposób, jak we wiodącym cytacie św. Edyty Stein. Znając różnorodne konotacje - antropologiczne, kulturowe, psychologiczne, teologiczne, a nawet moralne - nie będziemy ich dogłębnie analizować. Choć sama Edyta Stein nie użyła słowa „spełnienie”, po głębszym wczytaniu się w powyższy cytat okazuje się, że chodzi dokładnie o nie - „najwyższy osiągalny stopień bytowania”, osiągnięcie pełni człowieczeństwa indywidualnie dla każdego człowieka. Warto zaznaczyć również, iż samo pojęcie spełnienia wymaga koniecznie kontekstu, w jakim jest opisywane i/lub osoby, do której się odnosi. Spełnienie bez kontekstu i bez podmiotu nic nie znaczy.

Czym więc jest spełnienie? Przywołajmy na moment angielskie pojęcia: ful-fill-ment. Jest to rzeczownik od czasownika oznaczającego odczuwanie pełni, co nie jest już tak oczywiste w jego polskim odpowiedniku. Według twórcy psychologii pozytywnej Martina E. P. Saligmana spełnione życie to takie, w którym człowiek wykorzystuje swoje zdolności, talenty i potencjał, angażując się w coś, co jest dla niego autentyczne i ważne ${ }^{6}$. Dzięki temu w teraźniejszości doznaje przepływuㄱ i szczęścia, przeszłość odczuwa jako pełną satysfakcji i dobrostanu, a przyszłość widzi jako pełną nadziei i optymizmu ${ }^{8}$. Człowiek spełnia się więc wtedy, gdy wykorzystuje swoje zdolności do osiągania wyznaczonych przez siebie celów, świadomie służąc swoim wartościom i budując swoją tożsamość, swoje prawdziwe, autentyczne „ja”.

Czyż nie o to dokładnie chodzi w przywołanym cytacie Edyty Stein?

Każdemu odmierzone jest to, czym jest, oraz jego bycie. Można je jednak nazwać doskonałym o tyle, o ile osiągnęło właściwą sobie pełnię: jest całkowicie tym, czym ma być, i stoi na najwyższym osiągalnym dla niego stopniu bytowania ${ }^{9}$.

5 E. Stein, Byt skończony a byt wieczny, dz. cyt., s. 330.

6 Por. M. E. P. Seligman, M. Csikszentmihalyi, Positive psychology. A an introduction, „American Psychologist” 55 (2000) iss. 1, s. 11-12.

7 Przepływ (z ang. flow - doznanie uniesienia, uskrzydlenie) jest pojęciem wprowadzonym przez M. Csíkszentmihályiego i oznacza stan wyjątkowej satysfakcji osiągany dzięki całkowitemu zaangażowaniu w czynność, która go wywołuje. Por. M. Csíkszentmihályi, Przepływ: jak poprawić jakość życia: psychologia optymalnego doświadczenia, Taszów 2005, s. 28.

8 Por. M. E. P. Seligman, M. Csíkszentmihalyi, Positive psychology. An introduction, dz. cyt., S. 5 .

9 E. Stein, Byt skończony a byt wieczny, dz. cyt., s. 330. 
W tym fragmencie kluczem do zrozumienia spełnienia jest „osiągnięcie właściwej sobie pełni”. Każdy człowiek posiada swoją miarę owej pełni, a ona sama może być zarówno jakościowa, jak i ilościowa ${ }^{10}$. Spełnienie jest zadane, a nie dane, każdemu człowiekowi, jako zaproszenie do osiągnięcia przez niego pełni człowieczeństwa, człowieczeństwa na jego miarę i na jego możliwości. Spełnienie ze swej natury jest więc czymś, co może być odczuwane jedynie subiektywnie, dla każdego człowieka będzie bowiem ono oznaczało coś innego. Nie oznacza to, że spełnienie można osiągnąć w oderwaniu od siebie, drugiego człowieka, czy od swojego życia. Chodzi jedynie o indywidualne wypełnienie słowa „spełnienie”. Mówiąc o „zadaniu” człowiekowi spełnienia, odcinamy się od predestynacjonizmu czy teleologizmu, a zbliżamy się do Arystotelesowskiej i Tomaszowej koncepcji istnienia wewnętrznej potrzeby dążenia człowieka do integralności i doskonałości zapisanej w naturze ludzkiej ${ }^{11}$. Tymi odniesieniami zajmiemy się jednak w dalszej części tekstu. Wróćmy jeszcze do Edyty Stein:

Jeżeli jestestwo jest stworzeniem rozwijającym się, to najwyższa miara jego bytowania jest celem całego jego dążenia ${ }^{12}$.

Ten fragment cytatu uzupełnia wcześniejszy wątek dążenia przez człowieka do pełni. Odnosi się do rozwoju personalnego jednostki, który nie tylko jest możliwy, ale jest zadaniem do podjęcia. Podejmując rozwój, człowiek otwiera sobie możliwość dotarcia do najwyższej dla siebie „miary bytowania”, czyli rozwinięcia w sobie tego wszystkiego, co najlepsze i najdoskonalsze. Dla człowieka, który chce podjąć wezwanie do osiągnięcia swojej pełni, będzie ona celem jego życia. A osiągnąwszy ją, stanie się człowiekiem spełnionym.

Aby człowiek chciał podjąć pracę nad sobą, pracę nad własnym rozwojem, potrzebne jest coś jeszcze. Nieodłącznym składnikiem spełnienia, jego swoistego rodzaju przyczyną sprawczą, jest pragnienie ${ }^{13}$. Ojciec Zawada pisze:

${ }^{10}$ Odnosząc się do używanej chętnie w dzisiejszych czasach metafory: człowiek może odczuwać swoją pełnię jako szklanka, garnek, wiadro, jezioro, morze, ocean. Żadne odczuwanie pełni nie jest też uprzywilejowanie, lepsze ani gorsze. W zasadzie w ogóle nie powinno podlegać wartościowaniu.

${ }^{11}$ Por. Arystoteles, Etyka nikomachejska, tłum. D. Gromska, [w:] tegoż, Dzieła wszystkie, t. 5, Warszawa 1996, Eth. Nic. 1.8. 1099 a 13-21; 2.3. 1105 a 10-20.

${ }^{12}$ E. Stein, Byt skończony a byt wieczny, dz. cyt., s. 330.

13 M. Zawada ocD, Homo desiderans Deum..., dz. cyt., s. 19. 
Zarówno sfera biologiczna, jak psychiczna, aż po duchowy wymiar człowieka przejawiają swe istnienie w pragnieniach. W sferze organicznej pojawia się napięcie i niepokój związany z zachowaniem życia (głód, łaknienie). Pojawia się tu rodzaj pragnień, w których organizm jest pobudzony do zaspokojenia jakiegoś braku i ustaje wraz z zaspokojeniem. Są to pragnienia stałe, odnawialne, ukierunkowane przez instynkt na określone przedmioty (jedzenie, sen, obecność drugiego itd.). W sferze psychicznej powstają potrzeby: akceptacji, znaczenia, bezpieczeństwa itd. W sferze zaś ducha pojawia się m.in. $\mathrm{w}$ formie pragnienia prawdy, nieśmiertelności czy Boga ${ }^{14}$.

Pragnienia, które pojawiają się w człowieku, podlegają hierarchii i nie są równo cenne. Są pragnienia, które muszą zostać zaspokojone, aby zachować życie. Są takie, które powinny być zaspokojone, aby zapewnić człowiekowi lepszą jakość tego życia. Są wreszcie takie, które wkraczają w strefę tożsamości człowieka i jego duchowości. Tu pragnienia są wyborem człowieka. Wybór ten wymaga decyzji i konsekwencji. Jednocześnie człowiek bez owego wyboru niczego by nie chciał i niczego by nie osiągnął. W dzisiejszej psychologii i rozwoju osobistym zamiast pragnienia występuje raczej słowo „motywacja”. Przy czym dla potrzeb tych rozważań moglibyśmy powiedzieć, że motywacja pcha człowieka do celu, a pragnienie go pociąga. Jest więc czymś, co przewyższa motywację, działa dużo głębiej i obejmuje całe jestestwo człowieka. Pragnienie pociąga człowieka ku przekraczaniu swoich wyobrażeń o sobie - często ograniczających, swoich przekonań nierzadko blokujących, i ukazuje mu drogę do osiągnięcia jego własnej pełni. Pragnienie ma się do spełnienia tak, jak puste naczynie do naczynia już wypełnionego. Puste naczynie symbolizuje kształt pragnienia, nazywa go, konkretyzuje. Spełnienie natomiast jest wypełnianiem naczynia, zależnym od działania człowieka. W tym miejscu można przywołać innego wielkiego mistyka, św. Jana od Krzyża, którego wypowiedź będzie podsumowaniem powyższych rozważań:

Nie zadowalaj się małym i nie szukaj okruszyn, które spadają ze stołu Ojca twego, lecz wyszedłszy z siebie, wejdź do pełności i ciesz się w twojej chwale. Ukryj się w niej i raduj się, a zaspokoisz pragnienie swego serca ${ }^{15}$.

\footnotetext{
${ }^{14}$ Tamże.

${ }_{15}$ Św. Jan od Krzyża, Dzieła, tłum. B. Smyrak ocD, Kraków 1986, s. 89.
} 
W jaki jednak sposób spełnienie odnosi się do szczęścia? Jak owo szczęście należy zdefiniować, by ukazać, jaka jest korelacja między spełnieniem i szczęściem? Ciekawą i nośną odpowiedź można znaleźć w tekstach klasycznych filozofów, stosując do zrozumienia szczęścia i pełni klucz z omawianego cytatu Edyty Stein.

\section{Klasyczne pojęcie szczęścia}

Aby znaleźć odpowiedzi na pytanie o ewentualną tożsamość szczęścia i spełnienia, zatrzymajmy się przez chwilę nad pojęciem szczęścia u klasycznych filozofów. Sokrates widział istotę człowieka w rozumnej duszy, która jest podmiotem świadomym siebie. Doskonalenie duszy i doskonalenie rozumu, czyli nabywanie wiedzy i poznanie, jest tożsame u Sokratesa $\mathrm{z}$ cnotą ${ }^{16}$. Nawet więcej, tylko owa cnota może dać człowiekowi szczęście, bo „czyn dobry jest zarazem piękny i pożyteczny" ${ }^{\prime 1}$. Wiedząc, że coś jest dobre, człowiek nie może wybierać zła, wybierałby bowiem swoje nieszczęście ${ }^{18}$. Źródła szczęścia nie należy więc upatrywać w życzliwym losie, w przyjemnościach ciała czy w bogactwie. Szczęście leży w wyborze dobrych czynów. Przy czym „dobry” jest tu pojmowany w konkretny, choć nie do końca oczywisty sposób, o czym za chwilę. Oczywistość doświadczenia powodowała, że intelektualizm etyczny Sokratesa krytykowany był już przez jego współczesnych. A sam sens krytyki trafnie ujął później Owidiusz: „Video meliora proboque sed detriora sequor" ${ }^{\prime 1}$.

Warto jednak przez chwilę oderwać się od tej najprostszej, literalnej wręcz interpretacji etyki Mędrca z Aten. Szczęściem według niego jest „czynienie dobra”. Aby więc zrozumieć samo pojęcie szczęścia, konieczne jest zrozumienie dobra u Sokratesa. Wielu myślicieli uważa, że Sokrates był z gruntu prawym człowiekiem ${ }^{20}$. Postępował rzeczywiście tak, jak uważał za słuszne, czyli dobre. Przy czym dobre postępowanie oznaczało autentyczne przekonanie do danego czynu. Przekonanie, które było wewnętrzne, subiektywne, ale

\footnotetext{
${ }^{16}$ Por. Platon, Prot., 358 C-D.

17 Tamże.

${ }_{18}$ Por. tamże.

19 „Widzę i pochwalam to, co lepsze, lecz wybieram gorsze” (Owidiusz, Metamorfozy, Warszawa 2004, VII, 20-21).

${ }^{20}$ Por. F. Copleston, Historia filozofii, t. 1, Warszawa 1998, s. 103-107; za: W. T. Stace, A critical history of Greek philosophy, Macmillan 1920, s. 147-148.
} 
na tyle silne, że dawało człowiekowi wolność wyboru ${ }^{21}$. Nie była to więc sama wiedza, lecz wiedza zintegrowana z samym człowiekiem, z jego doświadczeniem życiowym, dążeniami, z jego samoświadomością. Współczesna psychologia nazywa taką postawę spójnością wewnętrzną: „chcę, myślę, mówię, czynię" jest wówczas u człowieka jednością. Całe postępowanie od myśli do czynu hołduje tym samym wartościom i jest koherentne na wszystkich poziomach. Spójność ukazuje integralność osobową we wszystkich wymiarach człowieczeństwa. Jeśli więc spojrzymy na stwierdzenie Sokratesa przez pryzmat spójności, że szczęście może dać człowiekowi tylko czynienie dobra, jawi się ono jako spójne postępowanie zgodnie z przyjętymi zasadami, przekonaniami, wartościami ${ }^{22}$. Mało tego, jest to postępowanie będące wyrazem tożsamości danego człowieka. Jeśli do tego zgodnego z tożsamością postępowania dołożymy jednostce wyznaczony cel życia, zgodnie z wymogami współczesnej psychologii pozytywnej, a jego postawa i wynikające z niej działanie będą drogą do osiągnięcia wyznaczonego celu, drogą, na której postępuje on $\mathrm{w}$ zgodzie $\mathrm{z}$ tym, kim jest, to docieramy do istoty spełnienia. Zgodnie bowiem z dzisiejszą wiedzą psychologiczną jedną z części spełnionego życia jest dążenie do realizacji określonego celu - w sposób intencjonalny, a nie przypadkowo ${ }^{23}$.

Nieco inaczej szczęście pojmuje Arystoteles. Mimo szeregu podobieństw odrzuca on podstawowe twierdzenie Sokratesa, że jeśli człowiek zna dobro, to je wybiera. W koncepcji Stagiryty to szczęście jest najwyższym dobrem, pojmowanym jako to, „, co go [człowieka] doskonali w aspekcie tego, co jest w nim najdoskonalsze"24. Szczytem szczęścia jest dążenie do najwyższego dobra i życie w kontemplacji tego dobra. Czym jest owo dobro? Według Arystotelesa człowiek może wyprowadzać ogólne zasady etyczne z własnych sądów. Potrzebuje je tylko zestawiać, porównywać, przeciwstawiać sobie, analizować i wreszcie wybierać ${ }^{25}$. Według Stagiryty największym szczęściem człowieka nie może być jednak rzeczywistość transcendentna, bo człowiek,

${ }^{21}$ Por. tamże.

${ }^{22}$ Por. tamże.

${ }^{23}$ Por. H. Kimsey-House, K. Kimsey-House, P. Sandahl, L. Withworth, Coaching koaktywny. Zmiany $w$ biznesie, zmiany $w \dot{z} y c i u$, tłum. M. Piechnik-Potęga, Warszawa 2014, s. 145.

${ }^{24}$ Eudajmonizm, [w:] Powszechna encyklopedii filozofii, Polskie Towarzystwo Tomasza z Akwinu, oprac. J. Paszyński, s. 3, http://www.ptta.pl/pef/pdf/e/eudajmonizm.pdf (5.05.2015).

${ }^{25}$ Por. Eth. Nic. 1216 b 32 n. oraz 1217 a 18 n. cytat za: F. Copleston, Historia filozofii, t. 1, dz. cyt., s. 302. 
jako istota duchowo-cielesna, nie byłby w stanie go osiągnąć. Mędrzec powie, że to w samym człowieku istnieją naturalne skłonności do dobra i „pójście za nimi w zachowaniu ogólnej postawy konsekwentnej harmonii i proporcji [...] stanowi dla niego życie etyczne"26. Szczęście człowiek może zatem znaleźć we własnym wnętrzu, gdyż jest do tego uzdolniony ${ }^{27}$. Dzisiejsza wiedza o rozwoju osobowym człowieka dostarcza podobnych stwierdzeń. Mówi się, że jednostka ma w sobie potencjał i wszystkie uzdolnienia potrzebne do osiągnięcia spełnienia. Żyjąc świadomie, poznaje siebie, zdobywa doświadczenie życiowe, wyodrębniając i hierarchizując własne wartości, by na ich podstawie odkrywać i wnioskować o własnej tożsamości ${ }^{28}$.

Stagiryta wprowadza jeszcze jedno rozróżnienie, którego metaforę możemy znaleźć w dzisiejszej psychologii i w wielu koncepcjach rozwoju osobistego. Arystoteles wprowadza cztery rozróżnienia odnośnie do bytu: materię, formę, możność i akt ${ }^{29}$. Posługując się tym rozróżnieniem jako metaforą, zastosujmy ten podział do pojęcia spełnienia. Według Stagiryty forma nie istnieje oddzielnie, jako samoistny byt, lecz nadaje postać i kształt materii. Każdy człowiek to swoistego rodzaju złożenie z formy i materii. Forma gatunkowa „człowiek” jest wspólna, różnimy się materią. Jednym z jej charakterystycznych przejawów są pragnienia. Są one różne dla różnych ludzi i w odmienny sposób przez nich realizowane. Stąd przyjmują one rozmaitą postać i kształt, jako odmienne dążenia i odrębne cele w życiu każdego człowieka. Oczywiście Arystoteles podkreśla, iż aby powiedzieć, że byt istnieje, musi on być czymś jednym ${ }^{30}$, a owa jedność jest jego transcendentalnym przymiotem. Nasuwa się oczywisty związek ze spójnością, która jednak jest bardziej postrzegana jako coś zadanego człowiekowi, coś, do czego jednostka pragnie dążyć. Niemniej może być także postrzegana jako jej możność. Tu wchodzimy w teorię dwóch momentów istnienia każdej rzeczy wg Stagiryty - możność i akt. W rozważanej metaforze koncepcji Arystotelesa możność jest owym naczyniem do wypełnienia, nasieniem, które jest już drzewem, rzeźbą ukrytą w kamieniu ${ }^{31}$. Każdy człowiek z natury nosi

${ }^{26}$ F. Copleston, Historia filozofii, t. 1, dz. cyt., s. 302.

${ }^{27}$ Por. Eth. Nic. 1094 b $27 \mathrm{n}$.

${ }^{28}$ Por. M. E. P. Seligman, M. Csikszentmihalyi, Positive psychology. An introduction, dz. cyt., S. 14 .

${ }^{29}$ Por. F. Copleston, Historia filozofii, t. 1, dz. cyt., s. 264-270.

${ }^{30}$ Por. Eth. Nic. 1096.

${ }^{31}$ Por. Arystoteles, Metafizyka, przeł. K. Leśniak, Warszawa 1984, s. 31. 
w sobie swoją maksymalną wersję, dzięki której może stać się w pełni tym, czym ma być. Jeśli się stanie, arystotelesowska możność zmienia się w akt, czyli to, co istnieje w rzeczywistości. Koresponduje to z przyjętą w tych rozważaniach, a opisaną wcześniej, zawartością słowa „spełnienie”, gdzie jest ono urzeczywistnieniem potencjału i możliwości tkwiących w człowieku.

Św. Tomasz w Traktacie o szczęściu inspiruje się Arystotelesem i podejmuje interesującą kwestię, zajmując się szczęściem kompleksowo, analizując wszystkie jego przejawy:

Szczęście można ujmować dwojako. Po pierwsze, ze względu na jego istotę ogólną. I wówczas jest rzeczą konieczną, aby każdy człowiek chciał szczęścia [...]. W inny jednak sposób możemy mówić o szczęściu, biorąc pod uwagę jego istotę szczególną, czyli to, na czym ono polega. I wówczas nie wszyscy rozpoznają szczęście $[. .$.$] w tym sensie, nie wszyscy go chcą { }^{32}$.

Dla Akwinaty prawdziwego szczęścia człowiek doświadczy dopiero po śmierci, zanurzając się w Bogu ${ }^{33}$, Najwyższym Dobru. Niemniej już tu na ziemi może dotknąć pewnego rodzaju szczęśliwości. Zdecydowanie odrzuca on szczęście jako posiadanie bogactwa, sławy, władzy, czy nawet cnoty.

Szczęście człowieka nie może zawierać się w żadnym dobru stworzonym. Szczęście jest bowiem dobrem doskonałym, które całkowicie zaspokaja pragnienie; inaczej nie byłoby ono celem ostatecznym, gdyby po jego osiągnięciu pozostawało jeszcze coś do pragnienia ${ }^{34}$.

Doktor Kościoła utożsamia najwyższe dobro z Bogiem i podkreśla istnienie pragnienia, które jest obecne w człowieku. To dzięki wypełnieniu tego pragnienia człowiek osiąga szczęście. Akwinata widzi również i akcentuje potrzebę podjęcia działania przez samego człowieka ${ }^{35}$. Owo działanie jest konieczne, aby człowiek osiągnął swoje najważniejsze cele i zamierzenia. Pomoc, zarówno przy ustalaniu celów, realizacji zamierzeń, jak i w osiągnięciu szczęścia, człowiek otrzymuje od strony swojego rozumu. Cel jest bowiem

\footnotetext{
${ }^{32}$ Św. Tomasz, Traktat o szczęściu, tłum. W. Galewicz, Kęty 2008, s. 116.

33 Por. tamże, s. 41.

${ }^{34}$ Tamże, s. 69.

35 Por. tamże.
} 
efektem używania intelektu, dążenie do jego realizacji natomiast św. Tomasz widzi jako rolę woli człowieka. Wola jest ukierunkowana na osiągnięcie celu, mając cały czas na uwadze dobro:

Jest zaś jasne, że wszystkie czynności, które pochodzą od pewnej władzy, są przez nią powodowane stosownie do natury przedmiotu. Przedmiotem woli zaś jest cel i dobro. Stąd też wszystkie czynności ludzkie muszą być wykonywane ze względu na pewien $\mathrm{cel}^{36}$.

Zanim przejdziemy jednak do związku między wyznaczeniem celu w życiu a spełnieniem, pozostaje jeszcze ostatnia kwestia. Jaka jest korelacja miedzy szczęściem i spełnieniem? Zarówno z powyższych rozważań, jak i cytowanych autorów, tak filozofów, jak i psychologów możemy wysnuć wniosek, że spełnienie jest czymś nadrzędnym w stosunku do szczęścia. To spełnienie jawi się jako przyczyna szczęścia, umożliwiająca jego zaistnienie i odczuwanie w życiu człowieka, a nie na odwrót. Odczucie pełni u Edyty Stein, Arystotelesowskie osiągnięcie pełni swoich możliwości w rzeczywistości czy wypełnienie pragnień u Akwinaty możemy postrzegać jako synonim spełnienia. Wyznaczenie celu w owym stanie spełnienia ma kluczowe znaczenie. Skoro sam św. Tomasz wprowadził pojęcie celu do definicji szczęścia, warto doprecyzować, co to pojęcie może zawierać.

\section{Rola celu w osiągnięciu spełnienia}

Św. Tomasz z Akwinu widzi konieczność ustalania celu w drodze do osiągnięcia szczęścia. Analogiczne twierdzenie możemy znaleźć we współczesnej psychologii, głównie pozytywnej oraz w różnych koncepcjach rozwoju osobistego człowieka. Imperatyw brzmi: ustal cel. Nie jest ambicją tych rozważań zagłębianie się we wszelkie zawiłości definiowania czy ustalenia celu. Interesujące jest jedynie pokazanie powiązań między wyznaczaniem celu a spełnieniem.

Czym w tym kontekście jest cel? W filozofii może być rozumiany jako, po pierwsze, kres działania (finis terminus) albo czynność (finis quo), dzięki

${ }^{36}$ Tamże. 
której osiąga się zamierzone dobro ${ }^{37}$. Może być również osobą (finis qui), której podporządkowuje się czynnik pożądający, lub motywem (finis quis gratia), ze względu na który dana czynność się odbywa ${ }^{38}$. W psychologii pozytywnej dzięki celom człowiek wie, dokąd zdąża oraz ma świadomość, w jaki sposób ukierunkować swoje działania. Cel jest również, co bardzo istotne w psychologii, skupieniem uwagi na dążeniu do czegoś konkretnego. Opisała to w trafnej metaforze Anne Scoular, twierdząc, że brak celu jest jak rozproszone w pomieszczeniu światło, które wprawdzie oświetla wszystko, ale niczego nie uwypukla w szczególny sposób, żaden przedmiot nie jest wyróżniony ${ }^{39}$. Wyznaczenie i sformułowanie celu jest skupieniem całego światła na jednej konkretnej rzeczy. W szczególnym przypadku promień światła może być tak skupiony, jak wiązka lasera i wtedy będzie w stanie ciąć najtwardsze przedmioty ${ }^{40}$. Przejście od rozproszonego światła do lasera pokazuje ogrom energii tkwiący w skupieniu uwagi na konkretnym celu.

Według psychologów i trenerów rozwoju osobistego w dzisiejszych czasach każde działanie podejmowane przez człowieka, od nauczania począwszy, a na zarządzaniu skończywszy, powinno mieć jasno zdefiniowane cele ${ }^{41}$. Istnieją nawet badania wskazujące na powiązanie braku celu z częstszym występowaniem depresji, a nawet jej pogłębianiem ${ }^{42}$. Wyniki tych badań są dosyć jasne. Wskazują one, że im bardziej sprecyzowany, dokładny i jaśniejszy będzie cel, który człowiek sobie ustali, tym większa szansa nie tylko na to, że go osiągnie, ale również na odzyskanie przez niego równowagi psychicznej i chęci do życia ${ }^{43}$.

Określenie celu wyznacza jasną, choć niekoniecznie prostą, drogę do spełnionego życia. Skoro człowiek dąży do spełnienia, powinien jasno określić,

37 Por. Cel, [w:] Powszechna encyklopedii filozofii, Polskie Towarzystwo Tomasza z Akwinu, opr. P. Gondek, s. 1-3, http://www.ptta.pl/pef/pdf/e/cel.pdf (3.05.2015) oraz Cel w aspekcie etycznym, opr. T. Styczeń, tamże.

${ }^{38}$ Por. tamże.

${ }^{39}$ Por. A. Scoular, Coaching biznesowy, Gdańsk 2013, s. 94.

${ }^{40}$ Por. tamże.

${ }^{41}$ Por. chociażby I. Opiełka-Majewska, Logodydaktyka, Gdańsk 2013; I. Opiełka-Majewska, Logodydaktyka w edukacji, Gdańsk 2014, Filozofia a zarzq̨dzanie, red. T. Oleksyn, Warszawa 2013.

${ }_{42}$ Por. wywiad, którego udzieliła dr J. Dickson na ten temat w WAMC Northeast Public Radio 22 kwietnia 2014 roku, http://wamc.org/post/dr-joanne-dickson-university-liverpool-depression-and-goals (12.04.2015).

${ }_{43}$ Por. tamże. 
gdzie owo spełnienie jest. Bez sprecyzowania celu może go osiągnąć, ale tego faktu w ogóle nie zauważyć. Braknie owego skupienia na czymś konkretnym i wyjątkowym, indywidualnym dla tej jednostki, co tylko dla niej będzie spełnieniem. Św. Tomasz mówił: „Miara ma być zgodna z mierzoną rzeczą” ${ }^{44}$.

W kontekście spełnienia to twierdzenie nabiera wyjątkowego znaczenia. Dla każdego człowieka miara spełnienia jest bowiem inna, nie ma ich co porównywać, czy tym bardziej wartościować. Czyjeś spełnienie nie jest gorsze lub lepsze od spełnienia drugiej osoby. Jest inne, właściwe tylko dla niej samej ${ }^{45}$.

Jest jeszcze jeden aspekt określenia i dążenia do osiągnięcia celu w życiu, który daje człowiekowi spełnienie. Cel nadaje życiu sens. Dobrze wyraża to tekst o. Zawady ${ }^{46}$ :

Człowiek dąży (pragnie) do tego, co ma dla niego największe znaczenie. Zależność pomiędzy wyobrażeniem celu, wewnętrznym tworzeniem sensu (wartości, znaczenia) a pragnieniem jest zdaniem S. Arietiego zasadnicza ${ }^{47}$. Alessandro Manenti w książce Żyć ideałami jeszcze mocniej rzecz kategoryzuje: Jeśli [człowiek] nie przystąpi do tworzenia własnego sensu, nie potrafi nigdy pragnąć ${ }^{48}$.

Wyznaczenie celów w życiu i pragnienie ich osiągnięcia nadaje życiu człowieka głęboki sens. Jest czymś, co go pociąga, ukierunkowuje, konstytuuje jego wartości osobiste i tożsamość.

\section{Zamiast zakończenia}

Czy dla człowieka xxı wieku jest możliwe osiągnięcie spełnienia? Z przytoczonych wcześniej rozważań wielkich filozofów wynikają dosyć jasne wnioski. Ich propozycje osiągnięcia spełnienia i szczęścia już tu na ziemi, są zaskakująco zbieżne i ciągle aktualne. A samo pytanie o możliwość

${ }^{44}$ Św. Tomasz, S. Th., k. 96, art. 2.

${ }^{45} \mathrm{~W}$ tym kontekście mogą pojawić się wątpliwości natury etycznej, np. czy spełnienie jednego człowieka może pociągać krzywdę innego. Odpowiedź na takie pytania, a nawet samo ich postawienie, nie wchodzi jednak w zakres tych rozważań.

${ }^{46}$ M. Zawada OCD, Homo desiderans Deum..., dz. cyt., s. 28.

${ }^{47}$ Por. S. Arieti, The will to be human, New York 1972, s. 36.

${ }^{8}$ A. Manenti, Żyć ideałami. Między lękiem a pragnieniami, tłum. J. Kochanowicz, Kraków 2005, s. 83 . 
osiągnięcia spełnienia, choć wydaje się proste, nie musi prowadzić do jednoznacznej odpowiedzi. Powiedzmy jednak: tak, jest możliwe. Jednakże pod pewnymi warunkami. Po pierwsze, człowiek musi wiedzieć, że istnieje możliwość osiągnięcia spełnienia już tu na ziemi. Takiego, jakie jest możliwe do osiągnięcia w tym życiu. Potem powinien poznać siebie na tyle, aby wiedzieć, jakie są jego wartości, jaka jest ich hierarchia oraz kim on naprawdę jest i kim się chce stawać. Tu jest miejsce na odkrycie i pielęgnowanie w sobie pragnienia, które będzie dla niego siłą napędową do o siągnięcia celu będącego dla niego źródłem spełnienia. Kres owego stawania się to wyznaczenie celu dla całego życia. Celu, do realizacji którego człowiek będzie używał swoich zdolności, talentów, a sama droga będzie mu dawała radość i satysfakcję. Wreszcie pozostaje konsekwentne i wytrwałe dążenie do celu. Spełnione życie nie jest życiem bez trudów, bólu czy potknięć. Spełnione życie jest osiągnięciem swojej pełni bez względu na te trudy.

\section{Bibliografia}

Arystoteles, Etyka nikomachejska, tłum. D. Gromska, [w:] tegoż, Dzieła wszystkie,

t. 5, Warszawa 1996, s. 1-327.

Arystoteles, Metafizyka, przeł. K. Leśniak, Warszawa 1984.

Copleston F., Historia filozofii, t. 1, Warszawa 1998.

Seligman M. E. P., Csikszentmihalyi M., Positive psychology. An introduction, „American Psychologist" 55 (2000) iss. 1, s. 5-14.

Stein E., Byt skończony a byt wieczny, tłum. I. Adamska ocD, Poznań 1995. Św. Tomasz, Traktat o szczęściu, tłum. W. Galewicz, Kęty 2008.

Zawada M. ocD, Homo desiderans Deum. Dynamika pragnienia Boga w wymiarze antropologiczno-duchowym, Kraków 2011.

\section{Streszczenie}

Każdy człowiek oczekuje od swojego życia czegoś więcej niż tylko zaspokojenia jego podstawowych potrzeb. Gdy tylko ma możliwość, szuka uzasadnienia swojego istnienia w świecie, celu swojego istnienia, szczęścia. Artykuł omawia temat spełnienia w życiu człowieka. Podejmuje próbę definicji spełnienia w oparciu o cytat z dzieła Edyty Stein. Rozważa korelację między pojęciami „spełnienie” i „szczęście”, 
odnosząc się do klasycznego rozumienia szczęścia u trzech wielkich filozofów: Sokratesa, Arystotelesa i św. Tomasza. Następnie analizuje rolę wyznaczenia celu w życiu w osiągnięciu spełnienia. Na koniec podejmuje próbę odpowiedzi na pytanie, czy osiągniecie spełnienia w dzisiejszych czasach w ogóle jest możliwe.

\section{Słowa kluczowe}

spełnienie, szczęście, pragnienie, cel

\section{Summary}

\section{In search of fulfillment}

Every man expects something more from his life than just satisfying its basic needs. As soon as the opportunity comes to justify his existence in the world, a man looks for existence and seeks happiness. The article takes the theme of human fulfillment in life. Attempting to meet the definition based on a quotation from the work of Edith Stein. Considering the correlation between the concepts of fulfillment and happiness its referring to the classical understanding of happiness of three great philosophers: Socrates, Aristotle and St. Thomas. Then examines the role of the designation of purpose in life to achieve fulfillment. At the end attempting to answer the question whether the achievement will be met today or ever.

\section{Keywords}

fulfillment, happiness, desire, purpose 